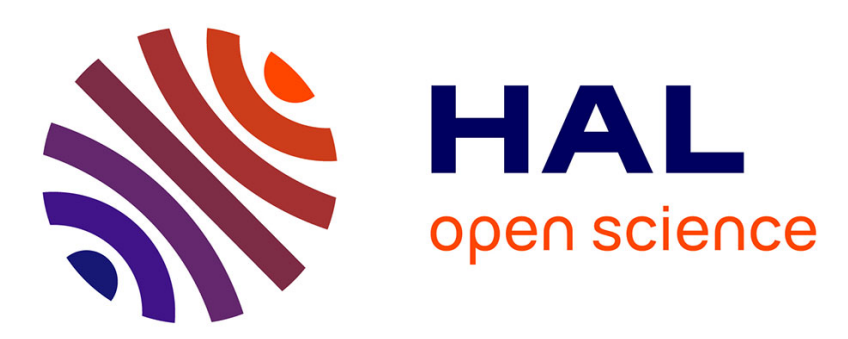

\title{
Evaluation of degradation and kinetics parameters of acid orange 7 through wet air oxidation process
}

\author{
Marine Minière, Olivier Boutin, Audrey Soric
}

\section{To cite this version:}

Marine Minière, Olivier Boutin, Audrey Soric. Evaluation of degradation and kinetics parameters of acid orange 7 through wet air oxidation process. Canadian Journal of Chemical Engineering, 2018, 96 (11), pp.2450-2454. 10.1002/cjce.23195 . hal-02114681

\section{HAL Id: hal-02114681 \\ https://hal-amu.archives-ouvertes.fr/hal-02114681}

Submitted on 29 Apr 2019

HAL is a multi-disciplinary open access archive for the deposit and dissemination of scientific research documents, whether they are published or not. The documents may come from teaching and research institutions in France or abroad, or from public or private research centers.
L'archive ouverte pluridisciplinaire HAL, est destinée au dépôt et à la diffusion de documents scientifiques de niveau recherche, publiés ou non, émanant des établissements d'enseignement et de recherche français ou étrangers, des laboratoires publics ou privés. 


\title{
EVALUATION OF DEGRADATION AND KINETICS PARAMETERS OF ACID ORANGE 7 THROUGH WET AIR OXIDATION PROCESS
}

\author{
Marine Minière, Olivier Boutin* and Audrey Soric \\ Aix Marseille Univ, CNRS, Centrale Marseille, M2P2, Marseille, France
}

\begin{abstract}
Among the industrial effluents presenting constraints to traditional biological treatments, those from textile industries are of particular concern. Wet air oxidation is an effective process that significantly increases biodegradability of the treated effluent. In this study, the advantage of this process was tested for the treatment of acid orange 7, a dye molecule used as a model textile effluent. Different experimental conditions of temperature (200 to $300^{\circ} \mathrm{C}$ ) and duration of treatment were used to determine its degradation yield during the wet air oxidation process, at a total pressure of $30 \mathrm{MPa}$. All these conditions led to complete degradation of acid orange 7, but residual Total Organic Carbon always remained. Oxidation byproducts were identified by the means of GC and HPLC analyses. Acetic acid remains the major compound not oxidized. These experiments resulted in the proposal of a reaction scheme associated with kinetic constants. Finally, the optimal conditions for the improvement of the biodegradability of the effluent were determined. This wet air oxidation process could then be coupled with a biological treatment to obtain an overall degradation meeting the criteria for release into the environment.
\end{abstract}

Keywords: coupled process, advanced oxidation process, biological treatment, process modelling, dye

\section{INTRODUCTION}

G iven the constraints and damage to the environment, the normative upgrading of industrial aqueous effluents is a priority. Among industrial effluents, textile effluents are one of the most problematic effluents. The textile industry consumes 60 to $400 \mathrm{~m}^{3}$ of water per ton of tissue produced. ${ }^{[1]}$ According to the production steps and the flexibility of raw materials used in the industry, the characteristics of textile effluents are extremely variable. In general, the final effluents are contaminated with a typical range of COD from 0.1 to $15 \mathrm{~g} \cdot \mathrm{L}^{-1}$. They are hardly biodegradable, with a $\mathrm{BOD}_{5} / \mathrm{COD}$ ratio of the order of $0.25 .^{[2,3]}$ The organic load of textile effluents consists mainly of extracts from raw materials, chemical additives, and dyes. The latter are particularly problematic in the treatment of textile effluents. Indeed, when they are discharged in the environment, dyes can be transformed under anaerobic conditions into toxic, carcinogenic, and mutagenic aromatic amines. ${ }^{[4,5]}$ The treatment of synthetic dyes is particularly difficult because they are developed to resist attacks once fixed to clothing, with a complex aromatic structure. ${ }^{[4]}$ Regarding current treatment technologies, activated carbon adsorption provides the best performance with simple implementation for dye disposal at an affordable price. ${ }^{[6]}$ However, this process consists in a transfer of pollution from the aqueous phase to a solid phase. Therefore, the treatment of solid wastes must be taken into account.

Thus, other processes such as wet air oxidation (WAO) need to be more investigated in order to improve textile effluent treatments. This process is mainly used to treat highly concentrated effluent, with a COD between 20 and $200 \mathrm{~g} \cdot \mathrm{L}^{-1}$. It has the advantage that its oxidizing agent is (usually) air. WAO is suitable for the treatment of effluents with an important suspended solids load. In addition, oxidation reactions are exothermic. This fact allows the WAO process to be potentially auto thermal when it is operated under optimum conditions that decrease the operative cost compared to other treatment processes. ${ }^{[7]}$ The objective is to study the system without catalyst. Indeed, in the context of pollution treatment, it is not necessarily a good thing to add catalyst that could be an additional pollutant, and necessitate further efficient separation and recycling to answer this problem. In this context, increasing temperature (and pressure if necessary) could be a good solution. To obtain accurate results on the WAO of textile effluents, typical compounds are selected: dyes. Two main classes of dyes are used in textile industries: azo and anthraquinone dyes. Azo dyes are the ones that are mostly used. Their structure has between one to four azo linkages attached to two groups; at least one of these is aromatic. Mantzavinos and Psillakis ${ }^{[8]}$ report that Acid Orange 7 (also called Orange II or A07) is one of the most frequently used.

In this context, the objectives of this work are to determine the degradation rates, the reaction mechanisms, and the kinetic parameters of WAO of AO7. These elements are needed for further modelling and simulation developments. More data give information on the evolution of the biodegradability of the effluent and the possibility to couple this process with a biological step.

\section{MATERIALS AND METHODS}

\section{Experimental Setup}

Figure 1 shows the batch process for wet air oxidation experiments (Top Industrie, France). It was composed of a $152.8 \mathrm{~mL}$ stainless steel reactor equipped with a stirrer (Rushton propeller, maximum speed $2000 \mathrm{rpm}$ ). It was connected to a volumetric pump allowing injection of either a liquid solution or gas phase (oxygen or nitrogen) at a given volume or pressure. Temperature was regulated thanks to a cooling jacket and an electric heating collar.

\footnotetext{
* Author to whom correspondence may be addressed.

E-mail address: olivier.boutin@univ-amu.fr
} 


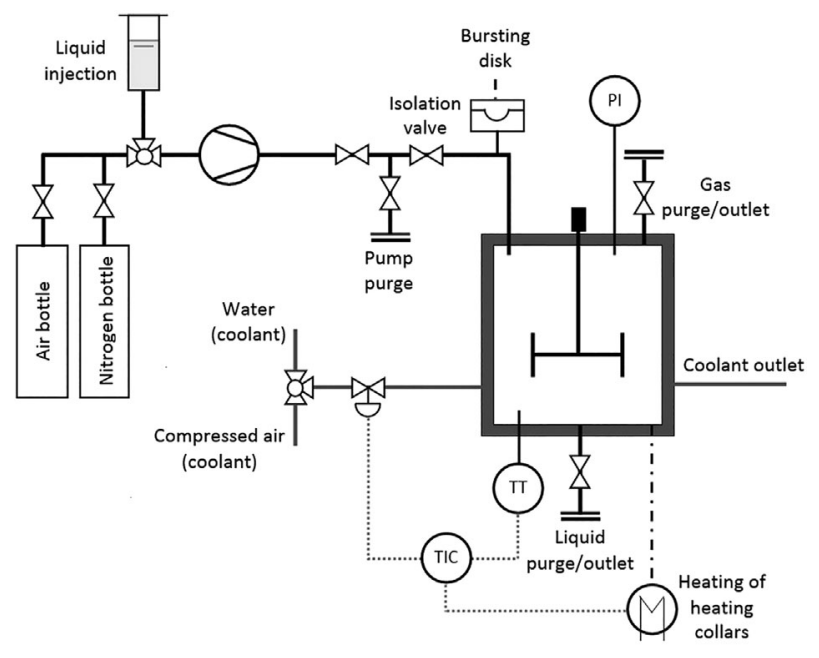

Figure 1. Wet air oxidation batch reactor.

Pressure was controlled thanks to a manometer inside the reactor vessel. Maximum temperature and pressure were set at $350{ }^{\circ} \mathrm{C}$ and $30 \mathrm{MPa}$. Liquid samples were collected via a valve located at the bottom of the reactor.

First, the reactor was made inert and pressurized with nitrogen. Then, $60 \mathrm{~mL}$ of aqueous solution of AO7 was injected and the injection valve in the reactor was closed. Stirring was started at $1000 \mathrm{rpm}$ because previous studies demonstrated that this speed avoided kinetic limitation by oxygen transfer. ${ }^{[9]}$ The reactor was next heated up to the operating temperature. At this time, air was injected, and the reaction began. Liquid samples were collected at the bottom of the reactor and analyzed. After each sampling, oxygen is added to maintain a constant pressure. Indeed, in a continuous bubble column (the industrial development for wet air oxidation process), the oxygen transfers along the column from the gas phase to the liquid phase and can be kept at a high concentration. In the batch experiment, when a sampling is done, pressure decreases. Two models have been tested: the one presented in this manuscript and another one considering the oxygen concentration. It appears that that there is no significant influence for kinetics determination, so the simplified model is proposed in the paper.

\section{Analytical Methods}

AO7 was analyzed by measuring the absorbance at $484 \mathrm{~nm}$ using a spectrophotometer (WTW PhotoLab ${ }^{\circledR} 7600$ UV-VIS). To have an overall assessment of degradation, Total Organic Carbon (TOC) measurements were performed using a Shimadzu ${ }^{\circledR}$ TOC meter. Some compounds were identified thanks to gas chromatography analyses (GC Varian 3800, FID Detector, vector gas: helium, column Varian CP-Sil 5CB). The compounds detected by this technique were phthalic acid, acetic acid, phenol, benzoic acid, and 2-naphthol. According to the $\mathrm{pH}$ of the sample analyzed, acids and alcohols may exist in their protonated or anionic form. The presence of these forms can influence their volatility and their interactions with the solid phase and thus modify the associated peak areas. Calibrations at different $\mathrm{pH}$ were therefore carried out on acetic and phthalic acids. Regarding acetic acid, the calibrations at $\mathrm{pH} 2.3,4.0$, and 6.5 showed no significant difference. On the contrary, the calibration of phthalic acid was modified according to the $\mathrm{pH}$ variation: the higher the $\mathrm{pH}$, the smaller the peak areas. When phthalic acid is in its ionized form, it becomes very polar and thus poorly retained by the column, and not very volatile. When the sample is sufficiently acidified, the ionized form becomes virtually non-existent. The addition of a higher amount of acid no longer influenced the results of the analyses. In order to consider these phenomena, samples containing phthalic acid were acidified by adding hydrochloric acid. Then this compound is almost totally in its protonated form. With these results, the evolution of the area of the peaks as a function of the phthalic acid concentration was obtained for different $\mathrm{pH}$ values. However, with these first analyses, a significant part of the carbonaceous compounds was not detected. A complementary method for the analysis of benzene sulfonic and phenol sulfonic acids by HPLC was developed (column Zorbax Eclipse plus C18, solvent: acetonitrile / water / formic acid $8 \%$ / $92 \%$ / $1 \%$ in mass percentage, UV detection at $215 \mathrm{~nm}$ ).

Taking into account these different analyses, TOC measurement showed that the majority of the organic composition was identified, for example $84 \%$ in the case of WAO of AO7 at $250{ }^{\circ} \mathrm{C}$ after $30 \mathrm{~min}$ of reaction (Figure 2).

The biogradability evolution can be estimated with results from literature. Indeed, AO7 presents a low biodegrability (or it is necessary to conduct experiments in a very specific way, difficult to reproduce in an industrial environment). ${ }^{[10]}$ On the contrary, phenolsulfonic acid presents a better biodegradability, especially if glucose and peptone are added. ${ }^{[1]}$ Finally, it is known that phthalic acid and acetic acid are easily biodegraded using the usual bacteria. $^{[12-15]}$

\section{Experimental Conditions}

The literature reports that WAO of AO7 has been carried out at concentrations between 80 and $1000 \mathrm{mg} \cdot \mathrm{L}^{-1}$, i.e. 120 to $1500 \mathrm{mg}_{\mathrm{COD}} \cdot \mathrm{L}^{-1} \cdot{ }^{[16]}$ However, COD of textile effluents can reach values of about $20 \mathrm{~g}_{\mathrm{COD}} \cdot \mathrm{L}^{-1}$, depending on the manufacturing step and the raw material used. ${ }^{[17]}$ Since WAO is particularly suitable for the treatment of effluents with high COD, it has been chosen to work at a COD content comparable to that of highly concentrated textile effluents. Thus, the initial COD of the treated solution in this study was $19.3 \mathrm{~g} \mathrm{COD} \cdot \mathrm{L}^{-1}$, ie $12.6 \mathrm{~g} \cdot \mathrm{L}^{-1}$ of AO7.

Lefèvre et al. ${ }^{[9]}$ showed that the reaction rates in the reactor were independent of the agitation rate above $1000 \mathrm{rpm}$. An air factor of 1.7 was set, i.e. an excess of oxygen of $70 \%$ with respect to the stoichiometric conditions. The total pressure (the influence of which has not been studied) has been set at $30 \mathrm{MPa}$, corresponding to a partial pressure of oxygen of 5.7 MPa. This value is much higher than those used in other studies, which are in the range of 0.5-3 MPa, because of a higher value of initial concentration of AO7 in this study. A wide temperature range, from 130 to $290{ }^{\circ} \mathrm{C}$, was previously studied and showed that degradation of AO7 was
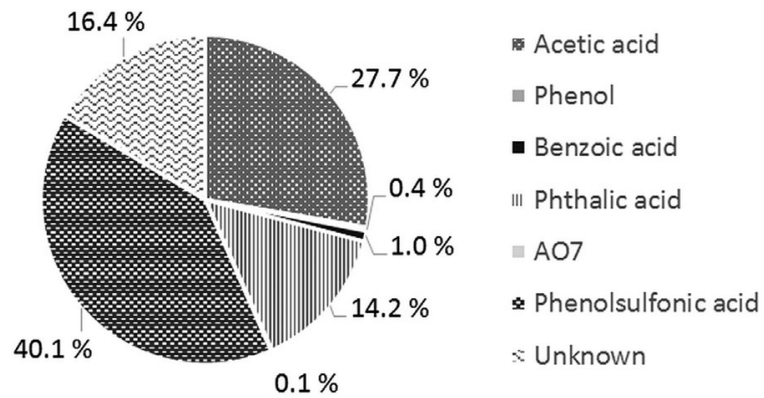

Figure 2. Composition of WAO effluent of $\mathrm{AO} 7$ at $250{ }^{\circ} \mathrm{C}$ after $30 \mathrm{~min}$ of oxidation reaction. 
very low for temperatures below $190^{\circ} \mathrm{C} .^{[18-21]}$ This previous result explains the range of temperature from 200 to $300{ }^{\circ} \mathrm{C}$ set for WAO of AO7 in this study.

Finally, many samplings were carried out to evaluate the influence of the duration of oxidation.

\section{RESULTS}

\section{AO7 Oxidation}

Many authors have shown that AO7 is unstable at high temperature. ${ }^{[18,22]}$ However, thermal degradation of the dye is correlated with a decrease of TOC. ${ }^{[18,23]}$ An experiment at $200{ }^{\circ} \mathrm{C}$ (and $30 \mathrm{MPa}$ ) without oxygen confirmed these results: after only $10 \mathrm{~min}$, nearly $11 \%$ of initial AO7 was degraded while the TOC remained constant. During the heating period, AO7 was converted into byproducts (naphthol and benzene sulfonic acid) ${ }^{[23]}$ without quantifiable loss of carbon. In order to minimize thermal degradation during WAO experiments, the reactor was preheated to the set point temperature in the presence of nitrogen and water only. Then a concentrated solution of AO7 was injected and the oxygen was quickly introduced up to the set point pressure.

Figure 3 shows the evolution of the degradation efficiency of AO7 as a function of oxidation time for different temperatures (the uncertainties in measured concentrations vary from 1 to $9 \%$, coming from different experimental runs and the GC accuracy). After 45 min almost all AO7 has been oxidized, with final concentrations of 0.5 to $9 \mathrm{mg} \cdot \mathrm{L}^{-1}$, whatever the temperature. On the other hand, the higher the temperature, the higher reaction yields are and the faster the oxidation is. These results are very close to those of Donlagic and Levec ${ }^{[23]}$ carried out in the same range of temperatures $\left(200\right.$ and $\left.240{ }^{\circ} \mathrm{C}\right)$.

TOC analysis showed that AO7 was not fully mineralized (Appendix 1), even at $300{ }^{\circ} \mathrm{C}$ after 15 min oxidation (87\% yield and a residual TOC of $890 \mathrm{mg} \cdot \mathrm{L}^{-1}$ ). These results are in good agreement with those of Donlagic and Levec ${ }^{[23]}$ at similar temperatures.

\section{Kinetics Modelling}

Figure 4 shows the evolution of the concentration of the compounds detected by GC during oxidation at $200{ }^{\circ} \mathrm{C}$. Phthalic and acetic acids are predominant, accounting for up to $15 \%$ and $32 \%$ of TOC, respectively. It is observed that phthalic acid is a reactional intermediate, which tends to disappear as the duration of oxidation increases. On the contrary, acetic acid tends to accumulate in the reaction medium.

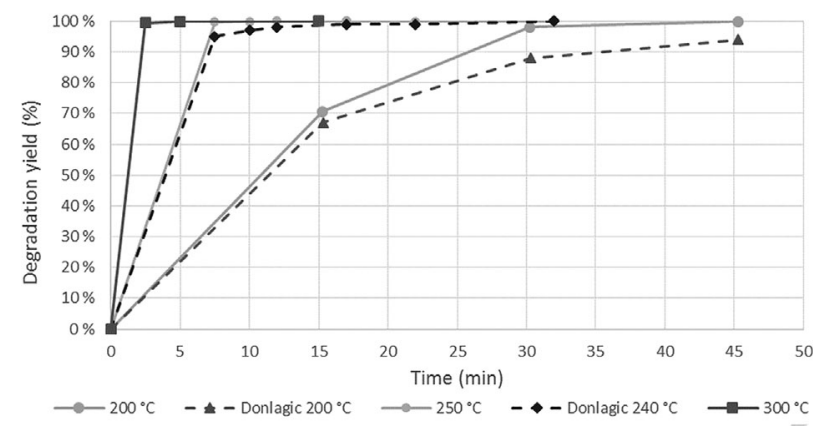

Figure 3. Temperature and reaction duration influence on $\mathrm{AO} 7$ degradation.
The only kinetic model for WAO of AO7 available in the literature was proposed by Donlagić and Levec. ${ }^{[23]}$ However, this model just focussed on two reactions: the conversion of AO7 into organic compounds and the oxidation of the latter to water and carbon dioxide. No distinction has been made between the various organic compounds formed: only the overall TOC content has been modelled.

From the composition of the samples obtained from WAO experiments at different temperatures, a kinetic model was proposed. It comprises the three main compounds identified and quantified: A07, phthalic acid (PA), and acetic acid (AA). In addition, the remaining organic carbon (largely due to phenolsulfonic acid and other aromatic compounds) was modelled as a single compound called "Aromatic Intermediate" or "ArI." The model includes the following four equations.

$$
\begin{aligned}
& \mathrm{C}_{16} \mathrm{H}_{12} \mathrm{~N}_{2} \mathrm{O}_{4} \mathrm{~S}+n_{1} \mathrm{O}_{2} \stackrel{r_{1}}{\rightarrow} \mathrm{ArI}+\mathrm{N}_{2}+\mathrm{H}_{2} \mathrm{SO}_{4} \\
& +n_{2} \mathrm{CO}_{2}+n_{3} \mathrm{H}_{2} \mathrm{O} \\
& \mathrm{ArI}+\mathrm{m}_{1} \mathrm{O}_{2} \stackrel{r_{2}}{\rightarrow} \mathrm{C}_{8} \mathrm{H}_{6} \mathrm{O}_{4}+m_{2} \mathrm{CO}_{2}+m_{3} \mathrm{H}_{2} \mathrm{O}+\mathrm{H}_{2} \mathrm{SO}_{4} \\
& \mathrm{C}_{8} \mathrm{H}_{6} \mathrm{O}_{4}+6.5 \mathrm{O}_{2} \stackrel{r_{3}}{\rightarrow} 0.5 \mathrm{C}_{2} \mathrm{H}_{4} \mathrm{O}_{2}+7 \mathrm{CO}_{2}+2 \mathrm{H}_{2} \mathrm{O} \\
& \mathrm{C}_{2} \mathrm{H}_{4} \mathrm{O}_{2}+2 \mathrm{O}_{2} \stackrel{\mathrm{r}_{4}}{\rightarrow} 2 \mathrm{CO}_{2}+2 \mathrm{H}_{2} \mathrm{O}
\end{aligned}
$$

The expression of the rate of each reaction is shown in Table 2 of Appendix 2. In the case of AO7, Donlagic and Levec ${ }^{[23]}$ also observed a first-order rate. Donlagić and Levec ${ }^{[23]}$ studied the oxidation of the organic carbon formed by second order kinetics. In the present case, second order kinetics was effectively suitable for the oxidation of aromatic compounds, while the oxidation of acetic acid was better modelled by first order kinetics. The concentration of each compound is expressed as a function of the extent of reactions $\xi$ in Table 3 of Appendix 2.

Four first order differential equations (Equations (5) to (8)) are finally obtained, $\xi_{i}$ being the extent of reaction and $k_{i}$ the Arrhenius constant of each reaction defined by Equations (1) to (4).

$$
\begin{aligned}
& \frac{d \xi_{1}}{d t}=k_{1}\left(n_{A O 7}^{0}-\xi_{1}\right) \\
& \frac{d \xi_{2}}{d t}=k_{2}\left(\xi_{1}-\xi_{2}\right)^{2}
\end{aligned}
$$

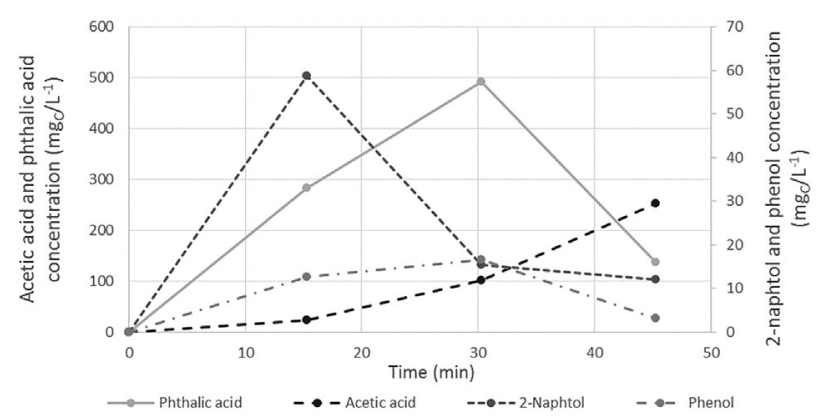

Figure 4. Evolution of the concentrations of reaction intermediates detected by GC for WAO of AO7 at $200{ }^{\circ} \mathrm{C}$. 


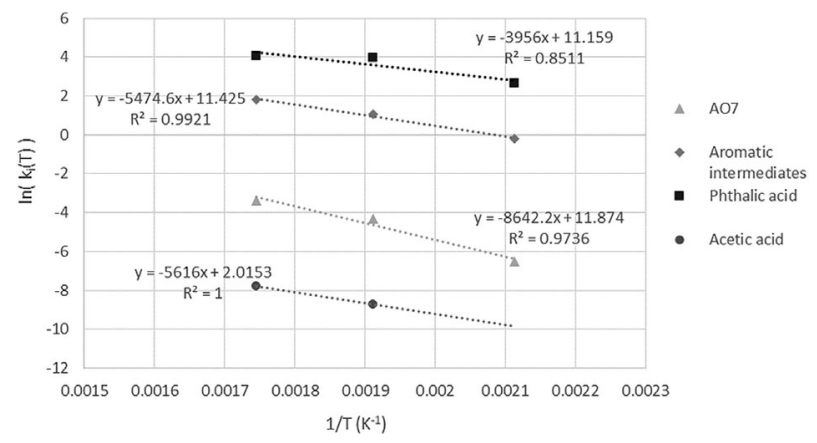

Figure 5. Calculation of the kinetic parameters of WAO of AO7.

$\frac{d \xi_{3}}{d t}=k_{3}\left(\xi_{2}-\xi_{3}\right)^{2}$

$\frac{d \xi_{4}}{d t}=k_{4}\left(0.5 \xi_{3}-\xi_{4}\right)$

In this system, the equations can be solved successively. The first equation makes it possible to calculate $k_{1}$ by minimizing the sum of least squares between experimental and modelled points. $\xi_{1}$ being determined, it is possible to determine $k_{2}$ in the same manner and so on. The equations were solved by the order 4 Runge Kutta method. Finally, for each compound, the constants calculated for each temperature were correlated with the Arrhenius law.

Figure 5 shows a good fit of the model for AO7 and aromatic intermediates with correlation coefficients higher than 0.97 . The kinetic constant associated with phthalic acid is slightly less well fitted, with a correlation coefficient of 0.85 . Concerning acetic acid, only two points have been obtained. Indeed, during WAO at $200{ }^{\circ} \mathrm{C}$, the kinetic constant associated with the oxidation of acetic acid was zero, showing its refractory nature to chemical oxidation at too low temperature.

Finally, the inherent calculated kinetic parameters are presented in Table 1. The activation energy obtained for the removal of AO7 was close to that obtained by Donlagic and Levec ${ }^{[21]}$ i.e. $68 \mathrm{~kJ} \cdot \mathrm{mol}^{-1}$. In this study, the authors obtained an activation energy associated with the TOC mineralization of $154 \mathrm{~kJ} \cdot \mathrm{mol}^{-1}$, which is significantly higher than the calculated activation energies of the study presented here.

Experimental and modelled curves are shown in Appendix 3. These figures show that the model reproduced the experimental results well at 250 and $300{ }^{\circ} \mathrm{C}$. However, large deviations occur at $200{ }^{\circ} \mathrm{C}$, showing that the model used can be further improved, for example by taking into account the oxygen concentration or by considering a larger number of reactions and reaction intermediates. Nevertheless, these results are satisfactory at $250{ }^{\circ} \mathrm{C}$ in order to carry out a simulation of WAO of AO7 at this temperature.

\section{CONCLUSION}

Textile effluents often contain hardly biodegradable compounds. This is mainly due to their high concentration of dyes. A means of increasing the biodegradability of these effluents is to carry out a pre-treatment by the wet air oxidation process. In this work, acid orange 7 was chosen as a dye model because it is particularly resistant to biodegradation. The analyses carried out on the various degraded samples made it possible to obtain the reaction scheme presented in Figure 6 . With this scheme, reaction constants were determined for each step, thus enabling the degradation kinetics of this compound to be modelled.

Regardless of the tested conditions, the results showed that degradation of AO7 was relatively easy. On the other hand, intermediate compounds are more difficult to oxidize, from the first aromatic molecules to acetic acid. The latter compound is known to be refractory to oxidation, even under the conditions studied in this work. To oxidize the overall carbonate matter into $\mathrm{CO}_{2}$, it would therefore be necessary to significantly increase the temperatures and the reaction times, which does not appear to be advantageous for an industrial treatment. This work gave significant results on the evolution of effluent composition during the treatment and conversion of initial molecules into biodegradable compounds such as acetic acid. Without proceeding further with the oxidation reaction, it is preferable to couple this process with an aerobic biological treatment method, in order to have an overall reduction of carbon matter and to discharge the treated effluent into the environment. This kind of

Table 1. Kinetics parameters of AO7

\begin{tabular}{|c|c|c|c|c|}
\hline Compound & $\mathrm{AO7}$ & Arl & PA & AA \\
\hline Activation energy $\left(\mathrm{kJ} \cdot \mathrm{mol}^{-1}\right)$ & 71.9 & 45.5 & 32.9 & 46.7 \\
\hline Pre-exponential factor & $1.43 .10^{5} \mathrm{~s}^{-1}$ & $9.16 .10^{4} \mathrm{~mol}^{-1} \cdot \mathrm{s}^{-1}$ & $7.02 .10^{4} \mathrm{~mol}^{-1} \cdot \mathrm{s}^{-1}$ & $7.5 \mathrm{~s}^{-1}$ \\
\hline
\end{tabular}

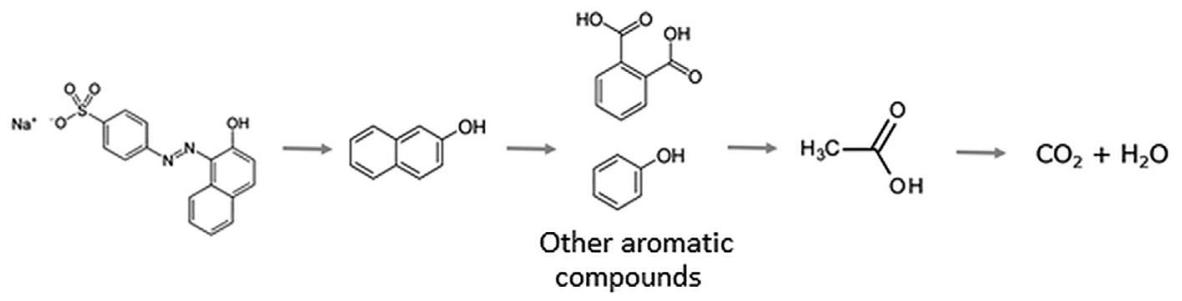

Figure 6. Reaction mechanism. 
approach has already been considered with phenol as the entering pollutant. ${ }^{[24]}$

\section{REFERENCES}

[1] M. Castillo, D. Barceló, Anal. Chim. Acta 2001, 426, 253.

[2] I. Oller, S. Malato, J. A. Sánchez-Pérez, Sci. Total Environ. 2011, 409, 4141.

[3] F. Ntuli, D. I. Omoregbe, P. K. Kuipa, E. Muzenda, M. Belaid, http://ir.nust.ac.zw:8080/jspui/handle/123456789/353, 2009, accessed February 12, 2014.

[4] I. M. Banat, P. Nigam, D. Singh, R. Marchant, Bioresource Technol. 1996, 58, 217.

[5] M. Solís, A. Solís, H. I. Pérez, N. Manjarrez, M. Flores, Process. Biochem. 2012, 47, 1723.

[6] A. Ahmad, S. H. Mohd-Setapar, C. S. Chuong, A. Khatoon, W. A. Wani, R. Kumar, RSC Adv. 2015, 5, 30801.

[7] S. Lefèvre, J. H. Ferrasse, R. Faucherand, A. Viand, O. Boutin, Energy 2012, 41, 175.

[8] D. Mantzavinos, E. Psillakis, J. Chem. Technol. Biot. 2004, $79,431$.

[9] S. Lefèvre, O. Boutin, J. H. Ferrasse, L. Malleret, R. Faucherand, A. Viand, Chemosphere 2011, 84, 1208.

[10] H. G. Kulla, F. Klausener, U. Meyer, B. Lüdeke, T. Leisinger, Arch. Microbiol. 1983, 135, 1.

[11] B.-R. Lim, H.-Y. Hu, K.-H. Ahn, K. Fujie, Process Biochem. 2005, 40, 2603.

[12] I. M. L. Castelo-Branco, R. C. Santos, R. M. Quinta-Ferreira, Int. J. Chem. React. Eng. 2007, 5, 1.

[13] C. A. Staples, D. R. Peterson, T. F. Parkerton, W. J. Adams, Chemosphere 1997, 35, 667.

[14] S. Chatterjee, T. K. Dutta, Chemosphere 2008, 70, 933.

[15] A. Bubinas, G. Giedraitytė, L. Kalèdienè, O. Nivinskiene, R. Butkiene, Open Life Sci. 2008, 3, 61.

[16] C. O’Neill, F. R. Hawkes, D. L. Hawkes, N. D. Lourenço, H. M. Pinheiro, W. Delée, J. Chem. Technol. Biot. 1999, 74, 1009.

[17] A. Rodríguez, G. Ovejero, M. D. Romero, C. Díaz, M. Barreiro, J. García, J. Supercrit. Fluids 2008, 46, 163.

[18] I. M. L. Castelo-Branco, R. C. Santos, R. M. Quinta-Ferreira, Int. J. Chem. React. Eng. 2007, 5, 235.

[19] I. Arslan-Alaton, J. L. Ferry, Dyes Pigments 2002, 54, 25.

[20] X. Zhong, L. Xiang, S. Royer, S. Valange, J. Barrault, H. Zhang, J. Chem. Technol. Biot. 2011, 86, 970.

[21] J. Donlagic, J. Levec, AIChE J. 1999, 45, 2571.

[22] I. I. Raffainer, P. Rudolf von Rohr, Ind. Eng. Chem. Res. 2001, 40, 1083.

[23] J. Donlagić, J. Levec, Ind. Eng. Chem. Res. 1997, 36, 3480.

[24] M. Minière, A. Soric, O. Boutin, Environ. Sci. Pollut. R. 2017, 24, 7693 . 